\title{
Electrolyte Engineering Toward Efficient Hydrogen Production Electrocatalysis with Oxygen-crossover Regulation under Densely Buffered Near-neutral pH Conditions \\ Tatsuya Shinagawa, and Kazuhiro Takanabe
}

J. Phys. Chem. C, Just Accepted Manuscript • DOI: 10.1021/acs.jpcc.5b12137 • Publication Date (Web): 30 Dec 2015

Downloaded from http://pubs.acs.org on January 6, 2016

\section{Just Accepted}

\begin{abstract}
"Just Accepted" manuscripts have been peer-reviewed and accepted for publication. They are posted online prior to technical editing, formatting for publication and author proofing. The American Chemical Society provides "Just Accepted" as a free service to the research community to expedite the dissemination of scientific material as soon as possible after acceptance. "Just Accepted" manuscripts appear in full in PDF format accompanied by an HTML abstract. "Just Accepted" manuscripts have been fully peer reviewed, but should not be considered the official version of record. They are accessible to all readers and citable by the Digital Object Identifier (DOI®). "Just Accepted" is an optional service offered to authors. Therefore, the "Just Accepted" Web site may not include all articles that will be published in the journal. After a manuscript is technically edited and formatted, it will be removed from the "Just Accepted" Web site and published as an ASAP article. Note that technical editing may introduce minor changes to the manuscript text and/or graphics which could affect content, and all legal disclaimers and ethical guidelines that apply to the journal pertain. ACS cannot be held responsible for errors or consequences arising from the use of information contained in these "Just Accepted" manuscripts.
\end{abstract}




\title{
Electrolyte Engineering toward Efficient Hydrogen
}

\author{
Production Electrocatalysis with Oxygen-crossover
}

\section{Regulation under Densely Buffered Near-neutral pH}

\section{Conditions}

\author{
Tatsuya Shinagawa and Kazuhiro Takanabe*
}

Division of Physical Sciences and Engineering, KAUST Catalysis Center (KCC), King Abdullah University of Science and Technology (KAUST), Thuwal 23955-6900, Saudi Arabia.

\begin{abstract}
This study tackles the core issues associated with near-neutral $\mathrm{pH}$ water splitting, particularly regarding electrolyte engineering in the electrocatalysis and product cross-over. The hydrogen evolution reaction (HER) was investigated on $\mathrm{Pt}$, $\mathrm{Ni}$ and $\mathrm{NiMo}$ catalysts in various concentrations of cations and anions to describe their performances by quantifying kinetics and mass-transport. The choice of electrolyte in terms of its identity and activity drastically altered the HER performance. Electrolyte properties (activity coefficient, kinematic viscosity and diffusion coefficient) accurately described the mass-transport contribution, which was easily
\end{abstract}


isolated when a highly active Pt catalyst was used. The HER rate on the Pt was maximized by tuning the solute concentration (typically $1.5-2.0 \mathrm{M}$ ). Moreover, the kinematic viscosity and oxygen solubility under such densely buffered conditions governed the oxygen mass-transport flux in the electrolyte, which in turn tuned the cross-over flux. At near-neutral $\mathrm{pH}$, as high as 90 \% selectivity toward the HER was achieved even under an oxygen saturated condition, where only a $40 \mathrm{mV}$ overpotential was needed to achieve $10 \mathrm{~mA} \mathrm{~cm}{ }^{-2}$ for the HER. This information can be regarded as an important milestone for achieving a highly efficient water splitting system at near-neutral $\mathrm{pH}$.

\section{Introduction}

The utilization of renewable energy as an energy source is one of the most promising concepts for the construction of a sustainable society. In recent decades, drastic progress in solar fuel production has occurred: photovoltaic cells can generate electricity from the sunlight, ${ }^{1-4}$ whereas photoelectrochemical $^{5}$ and photocatalytic $^{6-11}$ water splitting can directly produce hydrogen and oxygen by harvesting the sunlight. An electrolyzer can electrochemically split water molecules, ${ }^{12,13}$ which can be conjugated with the photovoltaic cells. ${ }^{14,15}$ Importantly, during the photoelectrochemical and photocatalytic water splitting, what takes place on the surface is electrocatalysis, in association with the photonic processes at the bulk of photon absorber and the interface between the photon absorber and electrocatalyst. ${ }^{11}$ Electrocatalysis will thus certainly play a crucial role in the solar fuel production process in the future.

Most of the studies regarding the electrochemical hydrogen evolution reaction (HER) have been carried out under kinetically-preferred, extremely acidic ${ }^{16-21}$ and alkaline conditions. ${ }^{20-27}$ 
Recently, some studies have been dedicated to the HER under near-neutral $\mathrm{pH}$ conditions. ${ }^{28-33}$ In typical supporting electrolytes, e.g., $\mathrm{Na}_{2} \mathrm{SO}_{4}$ or $\mathrm{NaClO}_{4},{ }^{30,31}$ the reactant for the HER at nearneutral $\mathrm{pH}$ has to be the water molecule to obtain a substantial hydrogen production rate (for example, approximately $-10 \mathrm{~mA} \mathrm{~cm}^{-2}$, corresponding to $\approx 10 \%$ solar to hydrogen efficiency). ${ }^{30-}$ ${ }^{32}$ Under such conditions, reactant mass-transport flux becomes slower than the surface hydronium ion reduction rate due to smaller hydronium ion activities. In unbuffered near-neutral $\mathrm{pH}$ electrolyte solutions, therefore, a huge additional overpotential is required to obtain higher electric currents compared with those at acidic or alkaline $\mathrm{pH}$ levels. ${ }^{32}$ In buffered electrolyte solutions, however, this two-step HER (hydronium ion reduction followed by water molecule reduction) is not practically observed and instead only a monotonic increase in reduction current is obtained. $^{28,29}$ The resultant onset potential is reported to be $\approx 0 \mathrm{~V}$ vs. RHE using Pt as an electrode, which is comparable to those in acidic and alkaline solutions. ${ }^{28,29,34}$ Some claim that the reactant under such condition is likely the weak acid itself, e.g., phosphate species $\left(\mathrm{H}_{2} \mathrm{PO}_{4}{ }^{-}\right.$ and $\left.\mathrm{HPO}_{4}{ }^{2-}\right) .{ }^{35-39}$ Previously, we reported that HER performances show a volcano-shaped trend with the solute concentration under buffered near-neutral $\mathrm{pH}$ conditions, exhibiting the highest performance at approximately $2 \mathrm{~mol} \mathrm{~L}^{-1}$ (in sodium phosphate solution at $\mathrm{pH} 5$ ). ${ }^{35}$ It is revealed that the HER under densely-buffered conditions over Pt electrocatalysts is predominantly governed by a mass-transport of weak acid ions. The concentration overpotential in a solution denser than $1.0 \mathrm{~mol} \mathrm{~L}^{-1}$ is calculated to be as high as $50 \%$ among kinetic overpotential, concentration overpotential and potential drop induced by the solution resistance. Although it has not been experimentally identified whether the weak acid ions directly react on the surface, mass-transport of a proton source (e.g., phosphate ions) to an area with close proximity to the catalyst surface predominantly determines the HER current on the Pt catalyst. This finding 
suggests that a fine electrolyte tuning will lead to much higher mass-transport and result in higher HER performances under near-neutral pH conditions.

On the other hand, oxygen gases evolve at the anode (oxygen evolution reaction, OER) during water splitting. Typically, active catalysts for the HER also show good oxygen reduction reaction (ORR) performances, as has been intensively studied, such as $\mathrm{Pt}^{40-43}$ and multi-metal catalysts. ${ }^{44-}$ ${ }^{49}$ Therefore, the evolved oxygen, which can be transported from the anode to the cathode, is reduced back to a water molecule. In typical water splitting cells for both electrochemical and photocatalytic water splitting, where use of a membrane is omitted, the cross-over of the product significantly lowers the total efficiency mainly via the undesired competitive reaction. Therefore, the concept of oxygen-tolerant HER is of great significance. ${ }^{50}$ Recently, some novel ways have been proposed to avoid this efficiency loss: core-shell structured materials that selectively suppress the oxygen molecule mass-transport to the reduction site $e^{10,11,51,52}$ and more selective catalysts toward the HER (high HER activity and poor ORR activity). ${ }^{53}$ Previously, we carried out an ORR study under densely-buffered conditions over a Pt electrocatalyst, showing that electrolyte properties (gas solubility, the kinematic viscosity and the diffusion coefficient) solely govern the oxygen mass-transport in the densely-buffered electrolyte solution. ${ }^{43}$ The study implies that a careful choice of electrolyte leads to a drastic reduction in oxygen mass-transport within the cell. The lowered oxygen mass-transport will result in reduced gas cross-over to the cathode, which in turn will increase the cell efficiency.

Efficient hydrogen production with controlling oxygen cross-over is thus crucial for efficient water splitting. According to the discussion above, we propose that this can be majorly achieved by utilizing a buffered solution to regulate mass-transport of the proton source (e.g., weak acid) and oxygen, irrespective of the catalyst nature. Herein, we quantitatively discuss the effects of 
solute identity on the HER and ORR, including the HER in the presence of oxygen, under densely-buffered conditions. Various kinds of electrolyte solutions $\left(\mathrm{KH}_{2} \mathrm{PO}_{4}, \mathrm{~K}_{2} \mathrm{HPO}_{4}, \mathrm{~K}_{3} \mathrm{PO}_{4}\right.$, $\mathrm{LiH}_{2} \mathrm{PO}_{4}, \mathrm{NaH}_{2} \mathrm{PO}_{4}, \mathrm{NaHCO}_{3}, \mathrm{HClO}_{4}, \mathrm{KOH}$ and a mixture of them) were used with a variety of solute concentrations $\left(0.01-3.0 \mathrm{~mol} \mathrm{~L}^{-1}\right)$. Observed HER performances under buffered nearneutral $\mathrm{pH}$ conditions were well reproduced by the diffusion coefficient and mean activity coefficient of weak acids $\left(\mathrm{H}_{2} \mathrm{PO}_{4}{ }^{-}, \mathrm{HPO}_{4}{ }^{2-}\right.$ etc. $)$. Additionally, the gas mass-transport flux was found to be universally and quantitatively described by the solution viscosity, the gas solubility and the diffusion coefficient. This benchmarking study disclosed that all the HER and ORR performances over Pt electrocatalysts were predictable, which allowed us to pin down the optimal conditions. Under such conditions $\left(1.5 \mathrm{~mol} \mathrm{~L}^{-1} \mathrm{NaH}_{2} \mathrm{PO}_{4}\right.$ or $1.5 \mathrm{~mol} \mathrm{~L}^{-1} 40 \% \mathrm{~K}_{2} \mathrm{HPO}_{4}$ $\left.+60 \% \mathrm{KH}_{2} \mathrm{PO}_{4}\right)$, the overpotential required to achieve $-10 \mathrm{~mA} \mathrm{~cm}^{-2}$, equivalent to an approximately $10 \%$ solar to hydrogen efficiency, was found to be less than $40 \mathrm{mV}$, where the selectivity to the HER in the presence of oxygen was as high as $90 \%$. The finding in this study, combined with the appropriate catalyst identity toward oxygen-tolerant hydrogen production, will lead to further progresses and practical applications of water splitting for future solar fuel production.

\section{Experimental methods}

A rotating disk electrode (RDE) configuration was applied to our study to control the masstransport phenomena unless otherwise specified. A polycrystalline Pt and Ni disk electrode with a $3.0 \mathrm{~mm}$ diameter $\left(0.071 \mathrm{~cm}^{2}\right.$ geometric surface area) was purchased from BAS, Inc. Before each measurement, the disk-electrode was polished first with $1 \mu \mathrm{m}$ diamond and then with 0.05 
$\mu \mathrm{m}$ alumina (both purchased from BAS, Inc.). The disk rotation speed was controlled at 1600$4900 \mathrm{rpm}$. NiMo electrocatalysts were electrochemically deposited onto Ni foam. ${ }^{54,55} \mathrm{~A} \mathrm{Ni}$ foam with $1 \mathrm{~cm} \times 1 \mathrm{~cm}$ geometric surface was immersed in the bath, which contains $0.02 \mathrm{~mol} \mathrm{~L}^{-1}$ sodium molybdate $\left(\mathrm{Na}_{2} \mathrm{MoO}_{4} \cdot 2 \mathrm{H}_{2} \mathrm{O}, 99.99 \%\right.$ Sigma-Aldrich), $0.04 \mathrm{~mol} \mathrm{~L}^{-1}$ nickel chloride $\left(\mathrm{NiCl}_{2} \cdot 6 \mathrm{H}_{2} \mathrm{O}\right.$, Sigma-Aldrich) and $0.89 \mathrm{~mol} \mathrm{~L}^{-1}$ sodium bicarbonate $\left(\mathrm{NaHCO}_{3}, 99.5-100.5 \%\right.$, Sigma-Aldrich). An electric current of $-77.5 \mathrm{~mA}$ was applied onto the Ni foam for $30 \mathrm{~min}$. The obtained NiMo electrode was then kept in $0.5 \mathrm{~mol} \mathrm{~L}^{-1} \mathrm{KOH}$ solution for $15 \mathrm{~h}$.

A three-electrode system was employed, in which a $\mathrm{KCl}$-saturated $\mathrm{Ag} / \mathrm{AgCl}$ electrode and a Pt and $\mathrm{Ni}$ wire were used as reference and counter electrodes, respectively. Various electrolyte solutions purchased from Sigma-Aldrich were used: $\mathrm{Na}_{2} \mathrm{SO}_{4}(\geq 99.99 \%), \mathrm{H}_{2} \mathrm{SO}_{4}(99.999 \%)$, $\mathrm{HClO}_{4}(99.999 \%), \mathrm{NaOH}(99.99 \%), \mathrm{KOH}(99.99 \%), \mathrm{Na}_{2} \mathrm{HPO}_{4}(99.5 \%), \mathrm{H}_{3} \mathrm{PO}_{4}(99.9 \%)$, $\mathrm{NaHCO}_{3}(\geq 99.95 \%), \mathrm{KH}_{2} \mathrm{PO}_{4}(\geq 98 \%), \mathrm{K}_{2} \mathrm{HPO}_{4}(\geq 99 \%)$ and $\mathrm{K}_{3} \mathrm{PO}_{4}(\geq 95 \%)$. Before and during all of the measurements, argon (99.999\%), hydrogen (produced using a NMH2 300 Hydrogen Generator, D. B. S. Strumenti Scientifici S.p.A.) or oxygen (99.9995 \%) was continuously supplied. Cyclic and linear-sweep voltammogram measurements were performed at $298 \mathrm{~K}$ with a scan rate of $50 \mathrm{mV} \mathrm{s}^{-1}$ using a 16-channel, research-grade potentiostat system (VMP3) purchased from BioLogic Science Instruments. All of the current densities described in this report are expressed in terms of the geometric electrode surface area, and all of the currentpotential relationships have been $i R$-corrected using measured impedance values $(100 \mathrm{kHz}$, amplitude $10 \mathrm{mV}$ and $298 \mathrm{~K}$ ) unless otherwise specified.

\section{Results and discussion}


In this paper, we demonstrate the concept that a fine tuning of an electrolyte leads to a controlled electrochemical hydrogen evolution reaction (HER) and oxygen reduction reaction (ORR) under buffered near-neutral conditions. First, the HER in various electrolyte solutions will be discussed, showing how apparent HER performances are altered by electrolyte solutions. Then, the ORR will be examined to evaluate gas mass-transport in the cell. The HER and ORR will be combined to describe the HER in the presence of oxygen. Finally, we discuss the beneficial effects of solution resistance at high solute concentrations.

\section{Hydrogen production}

The HER was investigated using Pt, Ni disk and NiMo electrode as a model catalyst in various electrolyte solutions under buffered conditions. Our previous study revealed that, in densely buffered solutions, the HER performances are shown to increase with the solute concentration at lower concentration regime, whereas further denser solutions lower mass-transport, resulting in poorer performances. ${ }^{35}$ The highest HER performance was obtained at approximately 2.0 mol $\mathrm{L}^{-1}$ in a sodium phosphate solution at $\mathrm{pH} 5$, where the concentration overpotential was calculated to be significantly huge (accounting for more than half of the required overpotential). ${ }^{35}$ If such is the case, then tuning electrolyte properties toward improved mass-transport is anticipated to enhance the HER at near-neutral $\mathrm{pH}$. The factors governing the apparent HER performance in the buffered solution are (1) diffusion coefficient and (2) mean activity coefficient of the electrolyte solution. ${ }^{35}$ The former, i.e., the diffusion coefficient $D$, is theoretically obtained by using the Stokes-Einstein equation: ${ }^{56}$

$$
D=\frac{k T}{6 \pi a \mu},
$$


where $k$ is Boltzmann's constant; $T$ is the absolute temperature; $a$ defines the effective size of an ion and $\mu$ denotes the solution viscosity. The equation shows that the diffusion coefficient is described by the effective sizes of ions in the solution ( $\approx$ hydrated size) and the solution viscosity at a given temperature. Among typical alkali cations, the following order was obtained regarding their sizes in the aqueous liquid phase (the size of ions with hydration): ${ }^{.57,58}$

$$
\mathrm{Li}^{+}>\mathrm{Na}^{+}>\mathrm{K}^{+}>\mathrm{Cs}^{+}
$$

For the anion in the buffered solution, e.g., phosphate, the following was found: ${ }^{57,58}$

$$
\mathrm{H}_{2} \mathrm{PO}_{4}{ }^{-} \geq \mathrm{HPO}_{4}{ }^{2-}
$$

The viscosity of such electrolyte solution was available in the literature, as follows: ${ }^{59}$

$$
\begin{array}{ll}
\mathrm{Li}^{+}-\mathrm{A}>\mathrm{Na}^{+}-\mathrm{A}>\mathrm{K}^{+}-\mathrm{A}>\mathrm{Cs}^{+}-\mathrm{A} & \left(\mathrm{A}=\mathrm{H}_{2} \mathrm{PO}_{4}{ }^{-} \text {and } \mathrm{HPO}_{4}{ }^{2-}\right) \\
\mathrm{M}-\mathrm{H}_{2} \mathrm{PO}_{4}{ }^{-}<\mathrm{M}-\mathrm{HPO}_{4}{ }^{2-} & \left(\mathrm{M}=\mathrm{Li}^{+}, \mathrm{Na}^{+}, \mathrm{K}^{+} \text {and } \mathrm{Cs}^{+}\right)
\end{array}
$$

(2)-(5) gave the order of the diffusion coefficient among simple alkali metal phosphate solutions:

$$
\begin{array}{ll}
\mathrm{Li}^{+}-\mathrm{A}<\mathrm{Na}^{+}-\mathrm{A}<\mathrm{K}^{+}-\mathrm{A}<\mathrm{Cs}^{+}-\mathrm{A} & \left(\mathrm{A}=\mathrm{H}_{2} \mathrm{PO}_{4}{ }^{-} \text {and } \mathrm{HPO}_{4}{ }^{2-}\right) \\
\mathrm{M}-\mathrm{H}_{2} \mathrm{PO}_{4}{ }^{-}>\mathrm{M}-\mathrm{HPO}_{4}{ }^{2-} & \left(\mathrm{M}=\mathrm{Li}^{+}, \mathrm{Na}^{+}, \mathrm{K}^{+} \text {and } \mathrm{Cs}^{+}\right)
\end{array}
$$


On the other hand, quantitative description of the mean activity coefficient is still under debate. $^{60-66}$ Nevertheless, the existing literature allows us to discuss it at least qualitatively. Based on the "like sees like" or "matching water affinity" concept, ${ }^{60}$ the following order of the mean activity coefficient $\gamma$ was obtained for the alkali metal phosphate solution:

$$
\begin{array}{ll}
\mathrm{Li}^{+}-\mathrm{A}>\mathrm{Na}^{+}-\mathrm{A}>\mathrm{K}^{+}-\mathrm{A}>\mathrm{Cs}^{+}-\mathrm{A} & \left(\mathrm{A}=\mathrm{H}_{2} \mathrm{PO}_{4}{ }^{-}\right) \\
\mathrm{Li}^{+}-\mathrm{A}<\mathrm{Na}^{+}-\mathrm{A}<\mathrm{K}^{+}-\mathrm{A}<\mathrm{Cs}^{+}-\mathrm{A} & \left(\mathrm{A}=\mathrm{HPO}_{4}{ }^{2-}\right)
\end{array}
$$

and

$$
\begin{aligned}
& \mathrm{M}-\mathrm{H}_{2} \mathrm{PO}_{4}{ }^{-}>\mathrm{M}^{-} \mathrm{HPO}_{4}{ }^{2-} \quad\left(\mathrm{M}=\mathrm{Li}^{+} \text {and } \mathrm{Na}^{+}\right)
\end{aligned}
$$

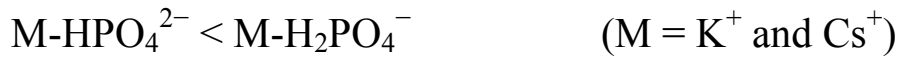

Because higher diffusion coefficients and mean activity coefficients are anticipated to result in apparently higher HER performances, the optimal conditions can be theoretically found at (a) Na- or $\mathrm{K}-\mathrm{H}_{2} \mathrm{PO}_{4}$, (b) $\mathrm{K}_{\mathrm{x}} \mathrm{H}_{3-\mathrm{x}} \mathrm{PO}_{4}(1<\mathrm{x}<2)$ and (c) $\mathrm{Cs}_{\mathrm{x}} \mathrm{H}_{3-\mathrm{x}} \mathrm{PO}_{4}(1<\mathrm{x}<2)$. This rationale is experimentally examined in the following (see also supporting information Figure S1 for a clear illustration of its theoretical trend).

The HER in $1.5 \mathrm{~mol} \mathrm{~L}^{-1} \mathrm{MH}_{2} \mathrm{PO}_{4}(\mathrm{M}=\mathrm{Li}, \mathrm{Na}$ and $\mathrm{K})$ was investigated, as shown in Figure 1. In all the cases, monotonically increasing currents were observed below $0 \mathrm{~V}$ vs. RHE. Regarding cation effects on the apparent HER in monobasic phosphate solutions, a volcano-shaped dependence was observed, e.g., $\mathrm{NaH}_{2} \mathrm{PO}_{4}$ showed the smallest overpotential among them. Notably, as will be discussed later in Figure 3, a higher HER performances were obtained in 
$\mathrm{NaH}_{2} \mathrm{PO}_{4}$ than those in $\mathrm{LiH}_{2} \mathrm{PO}_{4}$ and $\mathrm{KH}_{2} \mathrm{PO}_{4}$ for a wide range of concentrations $(0.1-1.5$ mol $\left.\mathrm{L}^{-1}\right)$. Additionally, in Figure 2, experimentally observed potentials reaching $-10 \mathrm{~mA} \mathrm{~cm}{ }^{-2}$ are compiled for various electrolyte solutions (see also supporting information Figure S2 for typical linear-sweep voltammograms over Pt disk electrode). Figure 2 a shows the potential as a function of coefficient $x$ in the $1.5 \mathrm{~mol} \mathrm{~L}^{-1} \mathrm{~K}_{\mathrm{x}} \mathrm{H}_{3-\mathrm{x}} \mathrm{PO}_{4}$, where $\mathrm{x}=1$ and $\mathrm{x}=2$ correspond to compositions equivalent to $\mathrm{KH}_{2} \mathrm{PO}_{4}$ and $\mathrm{K}_{2} \mathrm{HPO}_{4}$, respectively. The required overpotential first decreased with increasing $\mathrm{x}$ from 1.0, reaching the smallest $(35.0 \pm 1.3 \mathrm{mV})$ at $\mathrm{x} \approx 1.2$, and then monotonically increased. On the other hand, in Figure 2b, where the potential is compiled against $\mathrm{x}$ in 1.5 mol $\mathrm{L}^{-1} \mathrm{Na}_{\mathrm{x}} \mathrm{H}_{3-\mathrm{x}} \mathrm{PO}_{4}$, a monotonic increase in the overpotential with the $\mathrm{Na}^{+}$concentration was observed. It is worth noting that the solubility of $\mathrm{Na}_{2} \mathrm{HPO}_{4}(\mathrm{x}=2.0)$ is lower than $1.5 \mathrm{~mol} \mathrm{~L}-159$ From now on, the mixed solutions of $\mathrm{MH}_{2} \mathrm{PO}_{4}$ and $\mathrm{M}_{2} \mathrm{HPO}_{4}$ are referred as M-phosphate in this study. All the observations described in the figures are consistent with our theoretical rationale. If the observed electrolyte dependent HER performance originates from the electrolyte identity, the same observation is expected in the HER using different electrode. Indeed, the same electrolyte dependence was observed for Ni disk and NiMo electrode as shown in Figures S5 and S6. (also see supporting information Figures S3 and S4 for raw polarization curves over Ni disk and NiMo, respectively). The observation strongly supports our hypothesis: the HER under densely buffered conditions is predominantly determined by the diffusion properties of the electrolyte. It is worth emphasizing that under buffered near-neutral $\mathrm{pH}$ conditions, lower $\mathrm{pH}$ does not give higher HER performances. Figure S7 summarizes the overpotential with respect to the solution $\mathrm{pH}$, clearly indicating that free hydronium ions are not responsible for the HER performance. 
Additionally, all the typical electrolyte solutions $\left(\mathrm{KH}_{2} \mathrm{PO}_{4}, \mathrm{~K}_{2} \mathrm{HPO}_{4}, \mathrm{~K}_{3} \mathrm{PO}_{4}, \mathrm{LiH}_{2} \mathrm{PO}_{4}\right.$, $\mathrm{NaH}_{2} \mathrm{PO}_{4}, \mathrm{NaHCO}_{3}, \mathrm{H}_{2} \mathrm{SO}_{4}, \mathrm{HClO}_{4}$ and $\mathrm{KOH}$ ) were examined for the HER using the Pt disk electrode, as shown in Figure 3 (Also see Figure S5a for the Ni disk). In the figure, potentials reaching $-10 \mathrm{~mA} \mathrm{~cm}{ }^{-2}$ are plotted as a function of the solute concentration. In all the buffered near-neutral electrolyte solutions $\left(\mathrm{KH}_{2} \mathrm{PO}_{4}, \mathrm{~K}_{2} \mathrm{HPO}_{4}, \mathrm{LiH}_{2} \mathrm{PO}_{4}, \mathrm{NaH}_{2} \mathrm{PO}_{4}\right.$ and $\left.\mathrm{NaHCO}_{3}\right)$, the overpotential was volcano-shaped with the solute concentration, with its peak at approximately $1.5-2.0 \mathrm{~mol} \mathrm{~L}$. This potential-concentration relationship is most likely ascribable to the weak acid mass-transport, as we previously demonstrated. ${ }^{35}$ When the solute concentration was as small as $\leq 0.1 \mathrm{~mol} \mathrm{~L}^{-1}$, observed overpotentials for the HER were quite huge: as high as $330 \mathrm{mV}$ for $0.01 \mathrm{~mol} \mathrm{~L}^{-1} \mathrm{NaHCO}_{3}$, which is much larger than those for the typical alkaline conditions $\left(87.8 \pm 0.9 \mathrm{mV}\right.$ in $\left.0.1 \mathrm{~mol} \mathrm{~L}^{-1} \mathrm{KOH}\right)$. Interestingly, above that threshold concentration, higher HER performances were observed under the buffered near-neutral conditions than those in $\mathrm{KOH}$ or $\mathrm{K}_{3} \mathrm{PO}_{4}$ (alkaline) solutions. This likely results from the difference in the reactant: the proton or weak acid is the reactant under buffered near-neutral conditions, ${ }^{35-39}$ whereas the water molecule is reduced at alkaline $\mathrm{pH}^{30-32}$ In all of the concentration regimes, the HER was found to be the most facile under acidic conditions $\left(\mathrm{HClO}_{4}\right.$ and $\left.\mathrm{H}_{2} \mathrm{SO}_{4}\right)$. Notably, the solute concentration change in $\mathrm{HClO}_{4}$ electrolyte solution did not alter any apparent HER performances, consistent with the literature. ${ }^{30}$ One may wonder if denser $\mathrm{HClO}_{4}$ is more viscous, which is expected to lower the diffusion coefficient. According to the literature, the $\mathrm{HClO}_{4}$ viscosity is little altered by its concentration (see Figure S8). ${ }^{59,68}$ As a concluding remark in this section, the hydrogen production can indeed be tuned by the choice of electrolytes at near-neutral $\mathrm{pH}$. The highest performances for the HER were found in $1.5 \mathrm{~mol} \mathrm{~L}^{-1} \mathrm{NaH}_{2} \mathrm{PO}_{4}(37.8 \pm 1.0 \mathrm{mV})$ and $\mathrm{K}$ - 
phosphate (1.8 $\mathrm{mol} \mathrm{L}^{-1} \mathrm{~K}^{+} \& 1.5 \mathrm{~mol} \mathrm{~L}^{-1}$ phosphate), which is predictable from the electrolyte properties of effective ion sizes, solution viscosity and mean activity coefficient.

\section{Oxygen mass-transport}

The ORR was investigated to quantitatively evaluate oxygen mass-transport under the comparable conditions. According to the literature, ${ }^{67}$ the following Levich equation has been well established as describing the mass-transport limited current density (limiting diffusion current density):

$$
j_{L}=0.62 n F \varpi^{1 / 2} v^{-1 / 6} D^{2 / 3} \delta C
$$

where $j_{L}$ is the Levich current density; $n$ defines the number of involved electrons; $F$ is Faraday's constant; $\omega$ defines the disk rotation speed $\left(3600 \mathrm{rpm} \approx 377 \mathrm{rad} \mathrm{s}^{-1}\right) ; \mathrm{v}$ is the solution kinematic viscosity and $\delta C$ represents the difference in the reactant concentrations between the surface and bulk. Typically, when the equation is applied to the ORR, the properties of water are used to describe the limiting diffusion current. When denser solutions are utilized, however, the altered properties (kinematic viscosity, diffusion coefficient and reactant concentration) have to be taken into consideration. As we previously reported, ${ }^{43}$ under buffered near-neutral $\mathrm{pH}$ conditions, the solution viscosity increases, diffusion coefficient decreases and gas solubility decreases with increasing solute concentration. The observed limiting diffusion current for the ORR was found to be well described by these altered properties. ${ }^{43}$ The finding in the study can be applied to all gas conversion reactions: by tuning viscosity, the diffusion coefficient and gas solubility, the mass-transport can be well controlled. 
To prove this concept, various electrolyte solutions were used for our ORR study, e.g., $\mathrm{KH}_{2} \mathrm{PO}_{4}, \mathrm{~K}_{2} \mathrm{HPO}_{4}, \mathrm{~K}_{3} \mathrm{PO}_{4}, \mathrm{LiH}_{2} \mathrm{PO}_{4}, \mathrm{NaH}_{2} \mathrm{PO}_{4}, \mathrm{NaHCO}_{3}, \mathrm{HClO}_{4}$ and $\mathrm{KOH}$. The kinematic viscosity can be found in the literature, ${ }^{59,68}$ and the gas solubility is calculated using the Sechenov equation: ${ }^{69}$

$$
\log \left(\frac{c_{G, 0}}{c_{G}}\right)=\sum\left(h_{i}+h_{G}\right) c_{i},
$$

where $c_{G, 0}$ and $c_{G}$ represent the gas solubility in pure water and an electrolyte solution, respectively; $h_{i}$ and $h_{G}$ are constants that depend on the ion and gas, respectively, and $c_{i}$ is the molar salt concentration. The obtained oxygen solubility and kinematic viscosity for representative solutions are compiled in Figure 4. The oxygen solubility in all the buffered solutions decreased with the solute concentration (Figure $4 \mathrm{a}$ and $4 \mathrm{~b}$ ), and the kinematic viscosity was found to increase in denser solutions (Figure 4c). Using the Stokes-Einstein equation, diffusion coefficients in such electrolytes were calculated. With all the obtained values of kinematic viscosity, diffusion coefficient and gas solubility, limiting diffusion currents were calculated and are summarized in Figure 4d. In all cases, smaller limiting diffusion currents were obtained by increasing the solute concentration, showing the following order in different electrolyte solutions at a given solute concentration:

$$
\mathrm{NaHCO}_{3} \approx \mathrm{KH}_{2} \mathrm{PO}_{4}>\mathrm{NaH}_{2} \mathrm{PO}_{4}>\mathrm{K}_{2} \mathrm{HPO}_{4}
$$

This order is expected to reflect the trend of the oxygen mass-transport flux. 
The prediction was experimentally examined, as shown in Figure 5. In Figure 5a, all ORR limiting diffusion currents decreased with increasing solute concentration, except for $\mathrm{HClO}_{4}$, and the following order of limiting diffusion currents was obtained in the buffered near-neutral solutions:

$$
\mathrm{NaHCO}_{3}>\mathrm{KH}_{2} \mathrm{PO}_{4}>\mathrm{NaH}_{2} \mathrm{PO}_{4}>\mathrm{K}_{2} \mathrm{HPO}_{4}
$$

which totally agrees with the aforementioned expectation of (14). Therefore, it can be concluded that each electrolyte exhibits its properties, which solely determines the gas mass-transport. Notably, the identities of gases merely change their solubility and effective size; thus, the same argument is applicable to different gas conversion reactions, such as hydrogen oxidation reaction (HOR). As seen in Figure 5b, where the observed limiting diffusion currents for the HOR are plotted against the solute concentration, the same order as in (14) was obtained. These results reveal the universality of our concept for the electrocatalysis of dissolved gases: the masstransport can be well described by kinematic viscosity, the diffusion coefficient and the reactant concentration.

\section{Hydrogen production in the presence of oxygen}

Both the HER and ORR under densely-buffered conditions have been shown to be majorly governed by the electrolyte properties, i.e., effective sizes of ions, (kinematic) viscosity of the solution, mean activity coefficient and gas solubility. Tuning the electrolyte property can lead to improved overall hydrogen production rates and lowered oxygen mass-transport flux. Based on 
experimental observation, in this section, we compare the separately measured HER and ORR and also discuss the HER in the presence of oxygen.

In the previous sections, we have addressed current densities

(HER) at $-50 \mathrm{mV}$ vs. RHE in hydrogen

(ORR) at $400 \mathrm{mV}$ vs. RHE in oxygen (as the limiting diffusion current)

Additionally, we experimentally examined the hydrogen production with oxygen bubbling (see Figure S2 for raw linear-sweep voltammograms). Figure 6 compiles the measured current densities at $-50 \mathrm{mV}$ vs. RHE in the presence of oxygen against the sum of separately measured HER and ORR currents. A clearly linear relationship was observed, implying that the HER and ORR most likely do not interfere each other. This finding allows us to quantify the HER selectivity in the presence of oxygen (Faradaic efficiency to the HER) based on the separately measured HER and ORR:

$$
\text { Selectivity to the HER }=\frac{\text { HER }}{\text { HER }+ \text { ORR }} .
$$

In Figure 7, calculated selectivity to the HER is summarized for all the electrolyte solutions investigated: $\mathrm{KH}_{2} \mathrm{PO}_{4}, \mathrm{~K}_{2} \mathrm{HPO}_{4}, \mathrm{~K}_{3} \mathrm{PO}_{4}, \mathrm{LiH}_{2} \mathrm{PO}_{4}, \mathrm{NaH}_{2} \mathrm{PO}_{4}, \mathrm{NaHCO}_{3}, \mathrm{HClO}_{4}, \mathrm{KOH}, \mathrm{K}-$ phosphate and Na-phosphate (see also Figure S9 for a direct comparison of the HER vs. the ORR). Under buffered near-neutral conditions, increasing the solute concentration led to improved HER selectivity. This is consistent with those results that were separately described for the improved HER and lowered ORR in the previous sections. Notably, at alkaline $\mathrm{pH}(\mathrm{KOH}$ and $\mathrm{K}_{3} \mathrm{PO}_{4}$ ), the apparent HER activity was not simply increased with the solute concentration, as seen in Figure 3, whereas ORR limiting diffusion currents decreased with the solute 
concentration (Figure 5), which gives a different selectivity dependence on the solute concentration from those at near-neutral $\mathrm{pH}$. It is worth noting that although the selectivity in $\mathrm{HClO}_{4}$ is as high as approximately $80 \%$, the yield to ORR is the highest among the electrolyte solutions investigated as seen in Figures 5 and S9. The highest selectivity was found to be $89 \%$ (2.1 $\mathrm{mol} \mathrm{L}^{-1} \mathrm{~K}$-phosphate). The ones larger than $80 \%$ were observed in denser solutions: $>2.0$ mol L $\mathrm{LiH}_{2} \mathrm{PO}_{4},>1.5 \mathrm{~mol} \mathrm{~L}{ }^{-1} \mathrm{NaH}_{2} \mathrm{PO}_{4},>1.5 \mathrm{~mol} \mathrm{~L} \mathrm{~L}^{-1} \mathrm{KH}_{2} \mathrm{PO}_{4}, \mathrm{~K}$-phosphate and Naphosphate.

In Figure 8 typical linear-sweep voltammograms (LSVs) with various gases bubbling in the selected electrolyte solutions are shown (see also Figure S2 for more LSVs): (a) $2.1 \mathrm{~mol} \mathrm{~L}^{-1} \mathrm{~K}$ phosphate (highest HER selectivity), (b) $3.0 \mathrm{~mol} \mathrm{~L}^{-1} \mathrm{~K}_{2} \mathrm{HPO}_{4}$ (lowest ORR), (c) $1.0 \mathrm{~mol} \mathrm{~L}^{-1}$ $\mathrm{HClO}_{4}$ (typical acidic solution) and (d) $1.0 \mathrm{~mol} \mathrm{~L}{ }^{-1} \mathrm{KOH}$ (typical alkaline solution). Substantial differences between LSVs in oxygen and hydrogen bubbling were found in acidic and alkaline solutions. Under densely-buffered conditions, however, cathodic polarization curves in various gases below $0 \mathrm{~V}$ vs. RHE were too close to differentiate from each other. Specifically, when a solution was significantly dense, e.g., in $3.0 \mathrm{~mol} \mathrm{~L} \mathrm{~L}^{-1} \mathrm{~K}_{2} \mathrm{HPO}_{4}$, the polarization curves overlapped, showing negligibly small gas mass-transport. It should be emphasized that although the RDE configuration was applied to this study, the finding is applicable to other cases. The RDE gives a defined diffusion layer thickness, ${ }^{43}$ which is smaller than those in not stirred and poorly stirred systems. In a system where the RDE is not used, the mass-transport is thus anticipated to be much slower.

\section{$\underline{\text { Solution resistance }}$}


The overpotential in the electrolysis cell is predominantly composed of kinetic overpotential, concentration overpotential and voltage drop induced by the solution resistance. The ohmic loss by the solution resistance is one of the most significant parameters that determine the overall cell efficiency. Figure 9 compiles the measured resistivity of the various electrolyte solutions. In all cases, the resistivity decreased with increasing solute concentration, down to approximately 1.5 mol L $\mathrm{L}^{-1}$. Further denser solutions exhibited increased solution resistivity. The resistivity $\rho$ is theoretically described by the following equation: ${ }^{43,56}$

$$
\rho=\frac{6 \pi v a}{z^{2} e c F}
$$

which can be converted into the solution resistance $R$ :

$$
R=K_{\text {cell }} \rho
$$

where $K_{\text {cell }}$ is the cell constant; $v$ denotes the solution viscosity; $a$ represents the effective sizes of the ion; $z$ is the valence of the ion; $c$ stands for the solute concentration; $e$ is the elementary charge and $F$ is Faraday's constant. With respect to the solution resistivity, Equation 17 indicates that increasing the solute concentration leads to less resistivity, whereas too dense solution results in more resistivity due to increased viscosity. Thus, there should be optimal conditions where the solution resistance is minimized. Most of the buffered solutions showed minimum values at approximately $1.5-2.0 \mathrm{~mol} \mathrm{~L}^{-1}$, exhibiting interesting matching with the optimized values for diffusion contribution mentioned earlier. The measured solution resistivity of $\mathrm{KOH}$ monotonically decreased with increasing solute concentration $\left(0.1-2.0 \mathrm{~mol} \mathrm{~L}^{-1}\right)$. The measured 
solution resistivity of $2.0 \mathrm{~mol} \mathrm{~L}^{-1} \mathrm{KOH}$ in this study was approximately $6 \mathrm{ohm} \mathrm{cm}$. The literature shows that the minimum solution resistivity of $\mathrm{KOH}$ is obtained at approximately $6-8 \mathrm{~mol} \mathrm{~L}-1$ concentration: ${ }^{70} 1.56 \mathrm{ohm} \mathrm{cm},{ }^{71}$ which is also commercially used for alkaline electrolyzers. Although these resistivity are much smaller than those obtained under the neutral $\mathrm{pH}$ conditions with optimized solute concentrations $\left(11-16 \mathrm{ohm} \mathrm{cm}\right.$ in $\left.\mathrm{KH}_{2} \mathrm{PO}_{4}\right)$, the HER kinetics at alkaline $\mathrm{pH}$ is much sluggish compared to the optimized near-neutral $\mathrm{pH}$, as discussed in Figure 3 , likely due to differences in the reactants (water molecule vs. proton associated with weak acid). The lower HER reaction rate at alkaline $\mathrm{pH}$ makes the HER at near-neutral $\mathrm{pH}$ comparable to it: the cathodaic overvoltage and $i R$ loss to achieve $10 \mathrm{~mA} \mathrm{~cm}^{-2}$ water electrolysis is $130 \mathrm{mV}$ at nearneutral $\mathrm{pH}\left(1.5 \mathrm{~mol} \mathrm{~L}^{-1} \mathrm{~K}_{1.2} \mathrm{H}_{1.8} \mathrm{PO}_{4}\right)$ and $85 \mathrm{mV}$ to that at alkaline $\mathrm{pH}\left(0.5 \mathrm{~mol} \mathrm{~L}^{-1} \mathrm{KOH}: 85\right.$ $\mathrm{mV}$ ), with $1 \mathrm{~cm} \times 1 \mathrm{~cm}$ NiMo electrode and $1 \mathrm{~cm}$ of electrode distance $\left(K_{\text {cell }}=0.5 \mathrm{~cm}^{-1}\right)$. As the water splitting cell scales up (wider surface area and smaller electrode distance), the solution resistance becomes smaller due to smaller cell constant. Therefore, under more practical conditions, water electrolysis at near-neutral $\mathrm{pH}$ becomes greatly comparable to that at alkaline pH. Furthermore, it is emphasized that dual benefits are noticeable for the densely buffered condition compared to the commonly used buffer concentration $\left(\leq 1 \mathrm{~mol} \mathrm{~L}^{-1}\right)$ : improved diffusion properties of ions (reduced concentration overpotential) and improved conductivity (reduced $i R$ loss).

This study describes not only a very fundamental aspect of $\mathrm{H}_{2} / \mathrm{O}_{2}$ aqueous electrochemistry but also quite promising results, such as the electrolysis performance. Notably, when the potential applied to the reduction catalyst during water splitting (tentatively considered as $-50 \mathrm{mV}$ vs. RHE in this study) is more negative, the selectivity to the HER can be much higher. A careful choice of electrolyte solutions will most likely lead to drastically improved cell efficiency for 
electrochemical, photoelectrochemical and photocatalytic water splitting. The remaining aspects for kinetics, diffusion and solution resistance include their temperature and pressure dependence, which drastically alters overall cell efficiency. This study focused on ambient electrolysis associated with commonly-studied photoelectrochemical reactions, photocatalysis and biocatalysis. In the required operation conditions of the practical application, these aspects should be properly taken into account. The new insight pronounced in this study will advance and improve the existing water splitting devices and relevant chemistries.

\section{Conclusions}

Regarding oxygen cross-over-free hydrogen production, hydrogen evolution reaction (HER) and oxygen reduction reaction (ORR) were investigated in detail under near-neutral pH conditions. Our examination revealed that mass-transport properties of the electrolyte and the dissolved oxygen drastically affected both HER and ORR performance. This indicates that, irrespective of the catalyst, the performances are universally governed by the identity and activity of the solute. The factors determining the HER performance are the diffusion coefficient of buffered-species and the mean activity coefficient, the tuning of which gave expected improvement in overall HER currents. A benchmark study in various electrolytes revealed optimal conditions for the HER at near-neutral $\mathrm{pH}$, where $-10 \mathrm{~mA} \mathrm{~cm}^{-2}(\approx 10 \%$ solar to hydrogen efficiency) was achievable with an overpotential of less than $40 \mathrm{mV}$, which is superior to that at alkaline $\mathrm{pH}$ of $1.0-2.0 \mathrm{~mol} \mathrm{~L}^{-1} \mathrm{KOH}$ and becoming comparable to that at acidic $\mathrm{pH}$ of $0.1-1.5 \mathrm{M} \mathrm{HClO}_{4}$. On the contrary, ORR performance was governed predominantly by descriptive gas mass-transport flux associated with gas solubility, the kinematic viscosity and the diffusion coefficient. Combining the knowledge obtained in the HER and ORR study allowed us to quantify the 
hydrogen production in the presence of oxygen. At $-50 \mathrm{mV}$ vs. RHE, as high as $90 \%$ of selectivity to the HER in oxygen-saturated condition was observed in the $\mathrm{KH}_{2} \mathrm{PO}_{4}-\mathrm{K}_{2} \mathrm{HPO}_{4}$ mixture (ratio of $4 / 6$ at $1.5 \mathrm{~mol} \mathrm{~L}^{-1}$ ), where $-10 \mathrm{~mA} \mathrm{~cm}^{-2}$ for the HER was achieved over a Pt catalyst. Such densely buffered concentrations also minimize the solution resistance, giving additional improvement for the overall HER performance. This study showed the significance of electrolyte choice, which has been overlooked in many cases. Importantly, this study also highlighted a capacity of electrolysis at near-neutral $\mathrm{pH}$, where lower $\mathrm{CO}_{2}$ solubility and more material choices are provided. This fundamental yet crucial study will shed light on the wider application of electrolysis for solar fuel production.

\author{
ASSOCIATED CONTENT \\ Supporting Information. Linear sweep voltammograms over a Pt, Ni and NiMo electrode with \\ $\mathrm{H}_{2}$ or $\mathrm{O}_{2}$ bubbling; HER performances over the $\mathrm{Pt}$, Ni and NiMo electrode in function of \\ electrolyte concentration, electrolyte composition and $\mathrm{pH}$; gas solubility in acidic and alkaline \\ electrolyte solutions; kinematic viscosities of acidic and alkaline electrolyte solutions; direct \\ comparison between HER and ORR over Pt in various electrolyte solutions. This material is \\ available free of charge via the Internet at http://pubs.acs.org.
}

\title{
AUTHOR INFORMATION
}

\section{Corresponding Author}

* E-mail: kazuhiro.takanabe@kaust.edu.sa

Phone: +966128084485 


\section{Notes}

The authors declare no competing financial interests.

\section{ACKNOWLEDGMENT}

The research reported in this work was supported by the King Abdullah University of Science and Technology.

\section{REFERENCES}

(1) Callahan, D. M.; Munday, J. N.; Atwater, H. A. Solar Cell Light Trapping beyond the Ray Optic Limit. Nano Lett. 2012, 12, 214-218.

(2) Polman, A.; Atwater, H. A. Photonic Design Principles for Ultrahigh-Efficiency Photovoltaics. Nat. Mater. 2012, 11, 174-177.

(3) Li, G.; Zhu, R.; Yang, Y. Polymer Solar Cells. Nat. Photonics 2012, 6, 153-161.

(4) Hardin, B. E.; Snaith, H. J.; McGehee, M. D. The Renaissance of Dye-Sensitized Solar Cells. Nat. Photonics 2012, 6, 162-169.

(5) Krol, R.; Grätzel, M. Photoelectrochemical Hydrogen Production, Springer, New York, 2012.

(6) Tao, F.; Schneider, W. F.; Kamat, P. V. Heterogeneous Catalysis at Nanoscale for Energy Applications, John Wiley \& Sons, Inc., New Jersey, 2015. 
(7) Maeda, K.; Teramura, K.; Lu, D.; Takata, T.; Saito, N.; Inoue, Y.; Domen, K.

Photocatalyst Releasing Hydrogen from Water. Nature 2006, 440, 295.

(8) Kudo, A.; Miseki, Y. Heterogeneous Photocatalyst Materials for Water Splitting. Chem. Soc. Rev. 2009, 38, 253-278.

(9) Chen, X.; Shen, S.; Guo, L.; Mao, S. S. Semiconductor-based Photocatalytic Hydrogen Generation. Chem. Rev. 2010, 110, 6503-6570.

(10) Hisatomi, T.; Takanabe, K.; Domen, K. Photocatalytic Water-Splitting Reaction from Catalytic and Kinetic Perspectives. Catal. Lett. 2015, 145, 95-108.

(11) Takanabe, K. Solar Water Splitting using Semiconductor Photocatalyst Powders. Top Cur. Chem. 2016, 371, 73-103.

(12) White, P. E.; Bockris, J. O’M; Conway, B. E. Modern aspects of electrochemistry No. 15, Prenum Press, New York, 1983.

(13) Santos, D. M. F.; Sequeira, C. A. C.; Figueiredo, J. L. Hydrogen Production by Alkaline Water Electrolysis. Quim. Nova 2013, 36, 1176-1193.

(14) Barbir, F. PEM Electrolysis for Production of Hydrogen from Renewable Energy Sources. Solar Energy 2005, 78, 661-669.

(15) Zeng, K.; Zhang, D. Recent Progress in Alkaline Water Electrolysis for Hydrogen Production and Applications. Prog. Energy Combust. Sci. 2010, 36, 307-326.

(16) Trasatti, S. Work Function, Electronegativity, and Electrochemical Behavior of Metals. J. Electroanal. Chem. 1972, 39, 163-184. 
(17) Marković, N. M.; Grgur, B. N.; Ross, P. N. Temperature-Dependent Hydrogen Electrochemistry on Platinum Low-Index Single-Crystal Surfaces in Acid Solutions. J. Phys. Chem. B 1997, 101, 5405-5413.

(18) Greeley, J.; Jaramillo, T. F.; Bonde, J.; Chorkendorff, I; Nørskov, J. K. Computational High-Throughput Screening of Electrocatalytic Materials for Hydrogen Evolution. Nat. Mater. 2006, 5, 909-913.

(19) Durst, J.; Simon, C.; Hasché, F.; Gasteiger, H. A. Hydrogen Oxidation and Evolution Reaction Kinetics on Carbon Supported Pt, It, Rh, and Pd Electrocatalysts in Acidic Media. $J$. Electrochem. Soc. 2015, 162, F199-F203.

(20) Sheng, W.; Gasteiger, H. A.; Shao-Horn, Y. Hydrogen Oxidation and Evolution Reaction Kinetics on Platinum: Acid vs Alkaline Electrolytes. Y. J. Electrochem. Soc. 2010, 157, B1529B1536.

(21) Durst, J.; Siebel, A.; Simon, C.; Hasché, F.; Herranz, J.; Gasteiger, H. A. New Insights into the Electrochemical Hydrogen Oxidation and Evolution Reaction Mechanism. Energy Environ. Sci. 2014, 7, 2255-2260.

(22) Marković, N. M.; Sarraf, S. T.; Gasteiger, H. A.; Ross Jr., P. N. Hydrogen Electrochemistry on Platinum Low-Index Single-Crystal Surfaces in Alkaline Solution. J. Chem. Soc., Faraday Trans. 1996, 92, 3719-3725.

(23) Schmidt, T. J.; Ross Jr., P. N.; Markovic, N. M. Temperature Dependent Surface Electrochemistry on Pt Single Crystals in Alkaline Electrolytes. Part 2. The Hydrogen Evolution/Oxidation Reaction. J. Electroanal. Chem. 2002, 524-525, 252-260. 
(24) Subbaraman, R.; Tripkovic, D.; Strmcnik, D.; Chang, K.-C; Uchimura, M.; Paulikas, A. P.; Stamenkovic, V.; Markovic, N. M. Enhancing Hydrogen Evolution Activity in Water Splitting by Tailoring $\mathrm{Li}^{+}-\mathrm{Ni}(\mathrm{OH})_{2}$ Pt Interfaces. Science 2011, 334, 1256-1260.

(25) Subbaraman, R.; Tripkovic, D.; Chang, K.-C.; Strmcnik, D.; Paulikas, A. P.; Hirunsit, P.; Chan, M.; Greeley, J.; Stamenkovic, V.; Markovic, N. M. Trends in Activity for the Water Electrlyser Reactions on $3 d \mathrm{M}(\mathrm{Ni}, \mathrm{Co}, \mathrm{Fe}, \mathrm{Mn}) \mathrm{Hydr}(\mathrm{oxy})$ oxide Catalysts. Nat. Mater. 2013, 3313, $550-557$.

(26) Chen, C.; Kang, Y.; Huo, Z.; Zhu, Z.; Huang, W.; Xin, H. L.; Snyder, J. D.; Li, D.; Herron, J. A.; Mavrikakis, M. et al. Highly Crystalline Multimetallic Nanoframes with ThreeDimensional Electrocatalytic Surfaces. Science 2014, 343, 1339-1343.

(27) Yin, H.; Zhao, S.; Zhao, K.; Muqsit, A.; Tang, H.; Chang, L.; Zhao, H.; Gao, Y.; Tang, Z. Ultrathin Platinum Nanowires Grown on Single-Layered Nickel Hydroxide with High Hydrogen Evolution Activity. Nat. Comm. 2015, 6, 6430.

(28) Katsonuaros, I.; Meier, J. C.; Klemm, S. O.; Topalov, A. A.; Biedermann, P. U.; Auinger, M.; Mayrhofer, K. J. J. The Effective Surface pH During Reactions at the Solid-Liquid Interface. Electrochem. Comm. 2011, 13, 634-637.

(29) Auinger, M.; Katsounaros, I.; Meier, J. C.; Klemm, S. O.; Biedermann, P. U.; Topalov, A. A.; Rohwerde. M.; Mayrhofer, K. J. J. Near-Surface Ion Distribution and Buffer Effects During Electrochemical Reactions. Phys. Chem. Chem. Phys. 2011, 13, 16384-16394. 
(30) Strmcnik, D.; Uchimura, M.; Wang, C.; Subbaraman, R.; Danilovic, N.; Vliet, D.;

Paulikas, A. P.; Stamenkovic, V. R.; Markovic, N. M. Improving the Hydrogen Oxidation

Reaction Rate by Promotion of Hydroxyl Adsorption. Nat. Chem. 2013, 5, 300-306.

(31) Shinagawa, T.; Garcia-Esparz, A. T.; Takanabe, K. Mechanistic Switching by

Hydronium Ion Activity for Hydrogen Evolution and Oxidation over Polycrystalline Platinum

Disk and Platinum/Carbon Electrodes. ChemElectroChem 2014, 1, 1497-1507.

(32) Shinagawa, T.; Takanabe, K. Identification of Intrinsic Catalytic Activity for

Electrochemical Reduction of Water Molecules to Generate Hydrogen. Phys. Chem. Chem. Phys. 2015, 17, 15111-15114.

(33) Kumagai, H.; Minegishi, T.; Sato, N.; Yamada, T.; Kubot, J.; Domen, K. Efficient Solar Hydrogen Production from Neutral Electrolytes using Surface-Modified Cu(In,Ga)Se 2

Photocathodes. J. Mater. Chem. A 2015, 3, 8300-8307.

(34) Sheng, W.; Zhuang, Z.; Gao, M.; Zheng, J.; Chen, J. G.; Yan, Y. Correlating Hydrogen Oxidation and Evolution Activity on Platinum at Different $\mathrm{pH}$ with Measured Hydrogen Binding Energy. Nat. Comm. 2015, 6, 5848.

(35) Shinagawa, T.; Takanabe, K. Electrocatalytic Hydrogen Evolution under Densely Buffered Neutral pH Conditions. J. Phys. Chem. C 2015, 119, 20453-20458.

(36) Stojek, Z.; Clskowsk, M.; Osteryoung, J. G. Self-Enhancement of Voltammetric Wave of Weak Acid in the Absence of Supporting Electrolyte. Anal. Chem. 1994, 66, 1507-1512. 
(37) Silva, S. D.; Basséguy, R.; Bergel, A. Electrochemical Deprotonation of Phosphate on Stainless Steel. Electrochim. Acta 2004, 49, 4553-4561.

(38) Merrill, M. D.; Logan, B. E. Electrolyte Effects on Hydrogen Evolution and Solution Resistance in Microbial Electrolysis Cells. J. Power Sources 2009, 191, 203-208.

(39) Dilva Muñoz, L. D.; Bergel, A.; Féro, D.; Basséguy, R. Hydrogen Production by Electrolysis of a Phosphate Solution on a Stainless Steel Cathode. Int. J. Hydrogen Energy 2010, $35,8561-8568$.

(40) Marković, N. M.; Gasteiger, H. A.; Ross, Jr., P. N. Oxygen Reduction on Platinum LowIndex Single-Crystal Surfaces in Sulfuric Acid Solution: Rotating Ring-Pt $(h k l)$ Disk Studies. $J$. Phys. Chem. 1995, 99, 3411-3415.

(41) Maciá, M. D.; Campiña, J. M.; Herrero, E.; Feliu, J. M. On the Kinetics of Oxygen Reduction on Platinum Stepped Surfaces in Acidic Media. J. Electroanal. Chem. 2004, 564, 141150.

(42) Fabbri, E.; Taylor, S.; Rabis, A.; Levecque, P.; Conrad, O.; Kötz, R.; Schmidt, T. J. The Effect of Platinum Nanoparticle Distribution on Oxygen Electroreduction Activity and Selectivity. ChemCatChem 2014, 6, 1410-1418.

(43) Shinagawa, T.; Takanabe, K. Impact of Solute Concentration on the Electrocatalytic Conversion of Dissolved Gases in Buffered Solutions. J. Power Sources 2015, 287, 465-471. 
(44) Guo, S.; Li, D.; Zhu, H.; Zhang, S.; Markovic, N. M.; Stamenkovi, V. R.; Sun, S. FePt and CoPt Nanowires as Efficient Catalysts for the Oxygen Reduction Reaction. Angew. Chem. Int. Ed. 2013, 52, 3465-3468.

(45) Marković, N. M.; Schmidt, T. J.; Stamenković, V.; Ross, P. N. Oxygen Reduction Reaction on Pt and Pt Bimetallic Surfaces: a Selective Review. Fuel Cells 2001, 1, 105-116.

(46) Han, B.; Carlton, C. E.; Suntivich, J.; Xu, Z.; Shao-Horn, Y. Oxygen Reduction Activity and Stability Trends of Bimetallic $\mathrm{Pt}_{0.5} \mathrm{M}_{0.5}$ Nanoparticle in Acid. J. Phys. Chem. C 2015, 119, 3971-3978.

(47) Stamenkovic, V. R.; Fowler, B.; Mun, B. S.; Wang, G.; Ross, P. N.; Lucas, C. A.; Markovic, N. M. Improved Oxygen Reduction Activity on $\mathrm{Pt}_{3} \mathrm{Ni}(111)$ via Increased Surface Site Availability. Science 2007, 315, 493-497.

(48) Stamenkovic, V.; Nybm B. S.; Mayrhofer, K. J. J.; Ross, P. N.; Marković, N. M.; Rossmeisl, J.; Greeley, J.; Nørskov, J. K. Changing the Activity of Electrocatalysts for Oxygen Reduction by Tuning the Surface Electronic Structure. Angwe. Chem. Int. Ed. 2006, 45, 28972901.

(49) Huang, X.; Zhao, Z.; Cao, L.; Chen, Y.; Zhu, E.; Lin, Z.; Li, M.; Yan, A.; Zettl, A.; Wang, Y. M. et al. High-Performance Transition Metal-Doped $\mathrm{Pt}_{3} \mathrm{Ni}$ Octahedral for Oxygen Reduction Reaction. Science 2015, 348, 1230-1234.

(50) Wakerley, D. W.; Reisner, E. Oxygen-Tolerant Proton Reduction Catalysis: $\mathrm{Much}_{2}$ about Nothing? Energy Environ. Sci. 2015, 8, 2283-2295. 
(51) Yoshida, M.; Takanabe, K.; Maeda, K.; Ishikawa, A.; Kubota, J.; Sakata, Y.; Ikezawa, Y.; Domen, K. Role and Function of Noble-Metal/Cr-Layer Core/Shell Structure Cocatalysts for Photocatalytic Overall Water Splitting Studied by Model Electrodes. J. Phys. Chem. C 2009, $113,10151-10157$.

(52) Takata, T.; Pan, C.; Nakabayashi, M.; Shibata, N.; Domen, K. Fabrication of a CoreShell-Type Photocatalyst via Photodeposition of Group IV and V Transition Metal Oxyhydroxides: an Effective Surface Modification Method for Overall Water Splitting. J. Am. Chem. Soc. 2015, 137, 9627-9634.

(53) Garcia-Esparza, A. T.; Ca, D.; Ou, Y.; Kubota, J.; Domen, K.; Takanabe, K. Tungsten Carbide Nanoparticles as Efficient Cocatalysts for Photocatalytic Overall Water Splitting. ChemSusChem 2013, 6, 168-181.

(54) Conway, B. E.; Bai, L. $\mathrm{H}_{2}$ Evolution Kinetics at High Activity Ni-Mo-Cd Electrocoated Cathodes and Its Relation to Potential Dependence of Sorption of $\mathrm{H}^{*}$. Int. J. hydrogen Energy 1986, $11,533-540$.

(55) Stachurski, J. Z. O.; Pouli, D. P.; Ripa, J. A.; Pokrzyk, G. F. Low Overvoltage Hydrogen Cathodes. U.S. Patent 4354915, 1982.

(56) Atkins, P.; Paula, J. D. Atkins' physical chemistry, 8th ed., W. H. Freeman and Company, New York, 2006.

(57) Bockris, J. O’M; Reddy, A. K. N. Modern electrochemistry, Plenum Press, New York, 1970. 
(58) Israelachvili, J. N. Intermolecular and Surface Forces, 3rd ed., Elsevier, 2011.

(59) Haynes, W. M.; Lide, D. R. Handbook of Chemistry and Physics, 92nd ed., CEC Press: Boca Raton, FL, 2011.

(60) Kunz, W. Specific Ion Effects, World Scientific Publishing Co. Pte. Ltd., Singapore, 2010.

(61) Lyklema, J. Lyotropic Sequences in Colloid Stability Visited. Adv. Colloid Interface Sci. 2003, 100-102, 1-12.

(62) Kunz, W.; Henle, J.; Ninham, B. W. 'Zur Lehre von der Wirkung der Salze’ (About the Science of the Effect of Salts): Franz Hofmeister's Historical Papers. Cur. Op. Colloid Interface Sci. 2004, 9, 19-37.

(63) Collins, K. D. Ions from the Hofmeister Series and Osmolytes: Effects on Proteins in Solution and in the Crystallization Process. Methods 2004, 34, 300-311.

(64) Omta, A. W.; Kropman, M. F.; Woutersen, S.; Bakker, H. J. Negligible Effect of Ions on the Hydrogen-Bond Structure in Liquid Water. Science 2003, 301, 347-349.

(65) Tobias, D. J.; Hemminger, J. C. Getting Specific about Specific Ion Effects. Science 2008, 319, 1197-1198.

(66) Tielrooij, K. J.; Garcia-Araez, N.; Bonn, M.; Bakker, H. J. Cooperativity in Ion Hydration. Science 2010, 328, 1006-1009.

(67) Bard, A. J.; Faulkner, L. R. Electrochemical Method: Fundamentals and Applications; John Wiley \& Sons, Inc., New York, 2010. 
(68) Brickwedde, L. H. Properties of Aqueous Solutions of Perchloric Acid. Natl. Bur. Stand., 1949, 42, 309.

(69) Hermann, C.; Dewes, I.; Schumpe, A. The Estimation of Gas Solubilities in Salt Solutions. Chem. Eng. Sci., 1995, 50, 1673-1675.

(70) Gilliam, R. J.; Graydon, J. W.; Kirk, D. W.; Thorpe, S. J. A Review of Specific Conductivities of Potassium Hydroxide Solutions for Various Concentrations and Temperatures. Int. J. Hydrogen Energy 2007, 32, 359-364. 
Figure 1. Linear-sweep voltammograms using a polycrystalline Pt disk electrode in $1.5 \mathrm{~mol} \mathrm{~L}^{-1}$ $\mathrm{MH}_{2} \mathrm{PO}_{4}(\mathrm{M}: \mathrm{Li}, \mathrm{Na}$ and $\mathrm{K})$ electrolyte solutions with bubbling hydrogen (conditions: $-50 \mathrm{mV}$ $\mathrm{s}^{-1}, 3600 \mathrm{rpm}$ and $\left.298 \mathrm{~K}\right)$.

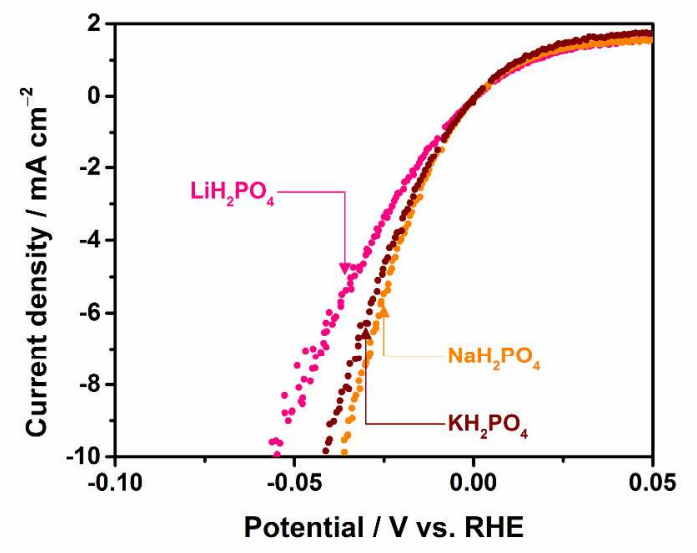

ACS Paragon Plus Environment 
Figure 2. Experimentally observed potentials reaching $-10 \mathrm{~mA} \mathrm{~cm}$ over a polycrystalline $\mathrm{Pt}$ disk electrode in $1.5 \mathrm{~mol} \mathrm{~L}^{-1}$ phosphate solutions with various (a) $\mathrm{K}^{+}$or (b) $\mathrm{Na}^{+}$concentrations with bubbling hydrogen (conditions: $-50 \mathrm{mV} \mathrm{s}^{-1}, 3600 \mathrm{rpm}$ and $298 \mathrm{~K}$ ).
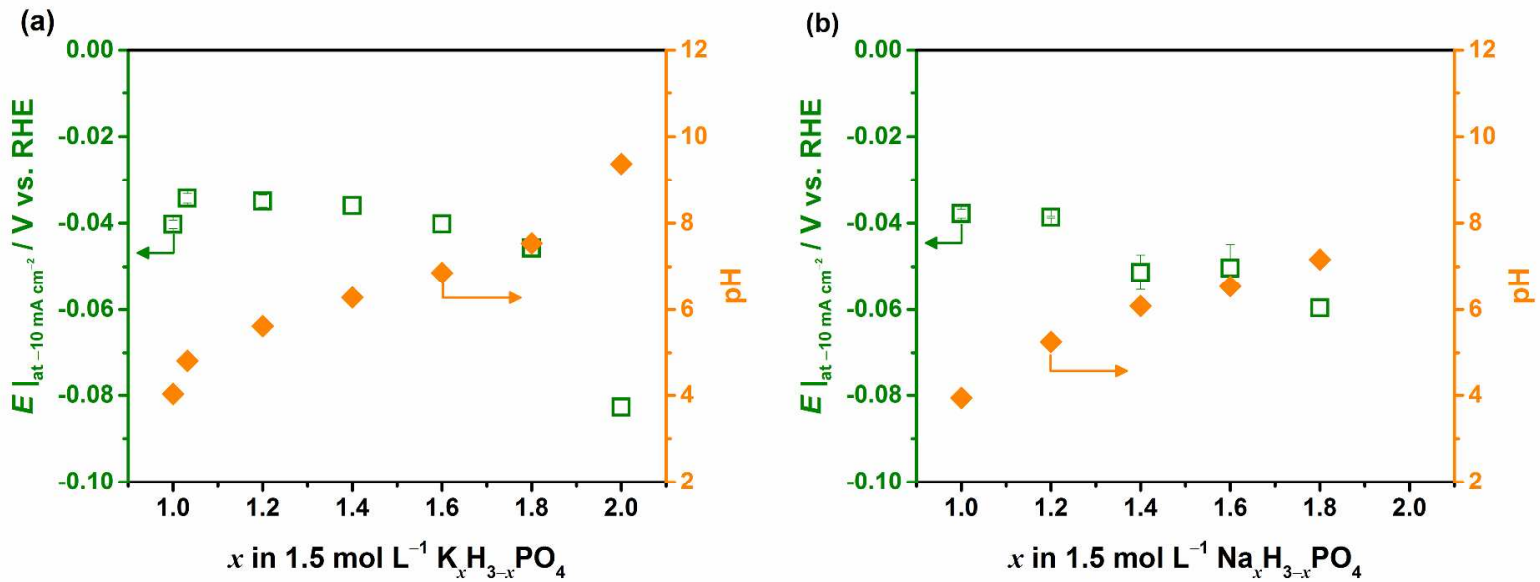
Figure 3. Experimentally measured potentials reaching $-10 \mathrm{~mA} \mathrm{~cm}^{-2}$ in various electrolyte solutions over a polycrystalline Pt disk electrode with bubbling hydrogen (conditions: $-50 \mathrm{mV}$ $\mathrm{s}^{-1}, 3600 \mathrm{rpm}$ and $\left.298 \mathrm{~K}\right)$.

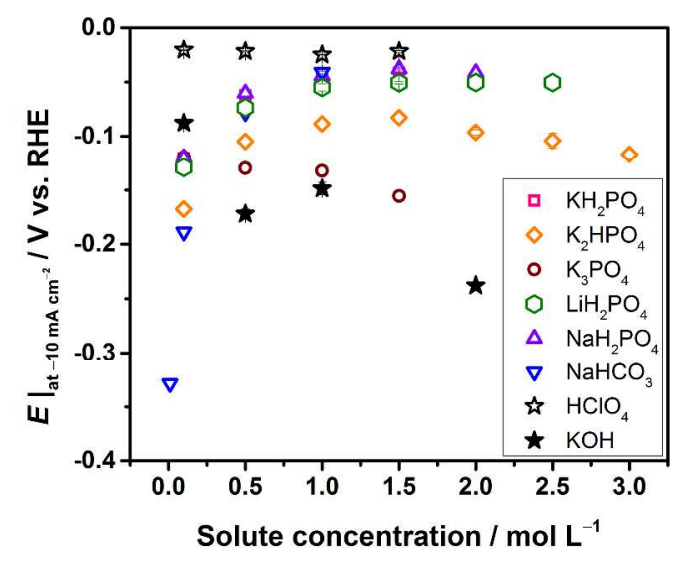


Figure 4. Oxygen solubility in various electrolyte solutions of (a) $\mathrm{Na}^{+}$with $\mathrm{H}_{2} \mathrm{PO}_{4}^{-}, \mathrm{HPO}_{4}{ }^{2-}$, $\mathrm{PO}_{4}{ }^{3-}, \mathrm{HCO}_{3}{ }^{-}$or $\mathrm{CO}_{3}{ }^{2-}$ and (b) $\mathrm{Li}^{+}, \mathrm{Na}^{+}, \mathrm{K}^{+}, \mathrm{Rb}^{+}$or $\mathrm{Cs}^{+}$with $\mathrm{H}_{2} \mathrm{PO}_{4}{ }^{-}$, calculated using the Sechenov equation; (c) kinematic viscosity of alkali metal $\left(\mathrm{Na}^{+}\right.$or $\left.\mathrm{K}^{+}\right)$with various anion $\left(\mathrm{H}_{2} \mathrm{PO}_{4}{ }^{-}, \mathrm{HPO}_{4}{ }^{2-}\right.$ or $\left.\mathrm{HCO}_{3}{ }^{-}\right)$electrolyte solutions, taken from the literature; ${ }^{59}$ (d) calculated limiting diffusion currents for the oxygen reduction reaction in various electrolyte solutions.
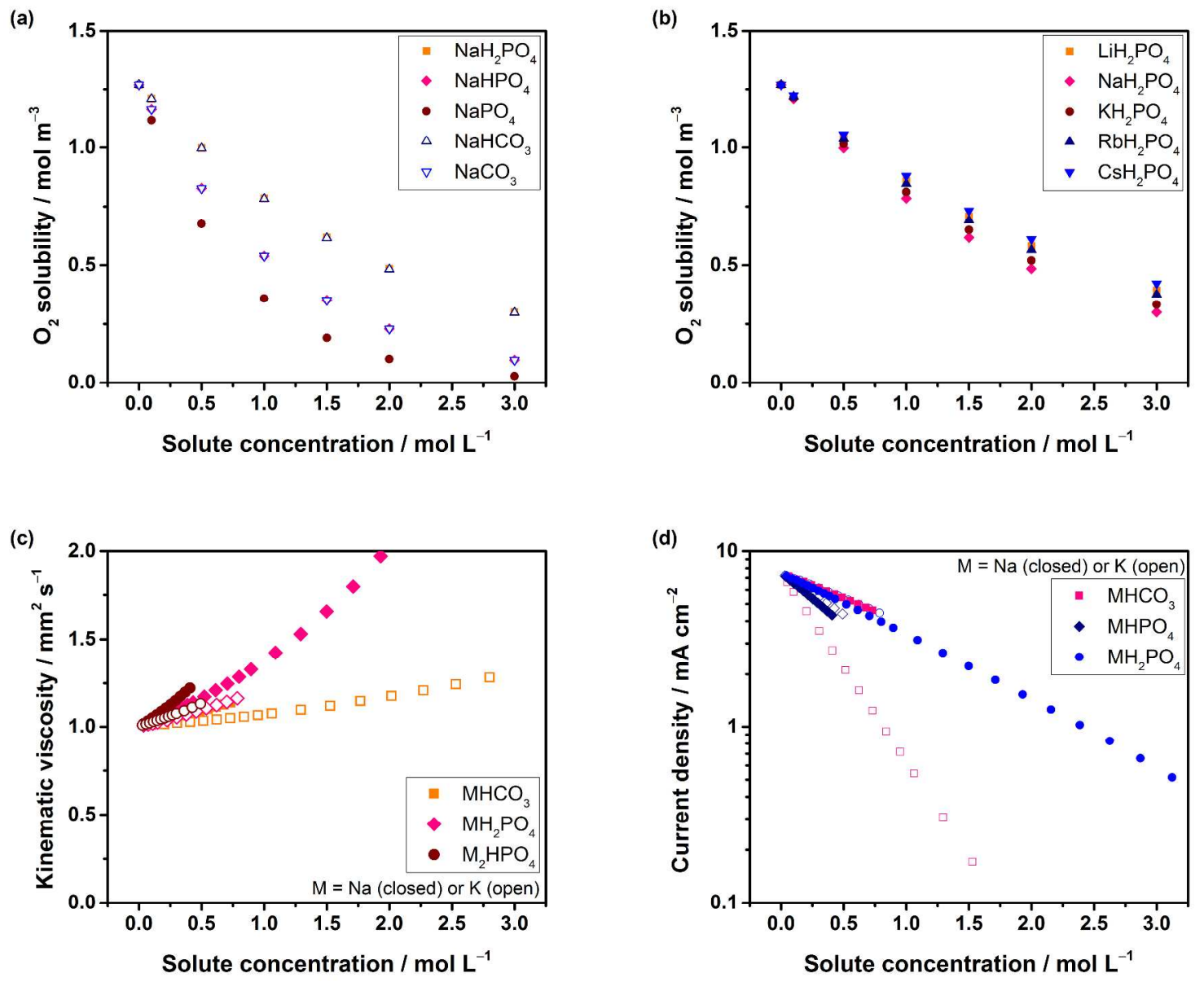
Figure 5. Experimentally observed electric current densities at $400 \mathrm{mV}$ vs. RHE in various electrolyte solutions over a polycrystalline Pt disk electrode with (a) oxygen and (b) hydrogen bubbling (conditions: $-50 \mathrm{mV} \mathrm{s}^{-1}, 3600 \mathrm{rpm}, 298 \mathrm{~K}$ ).
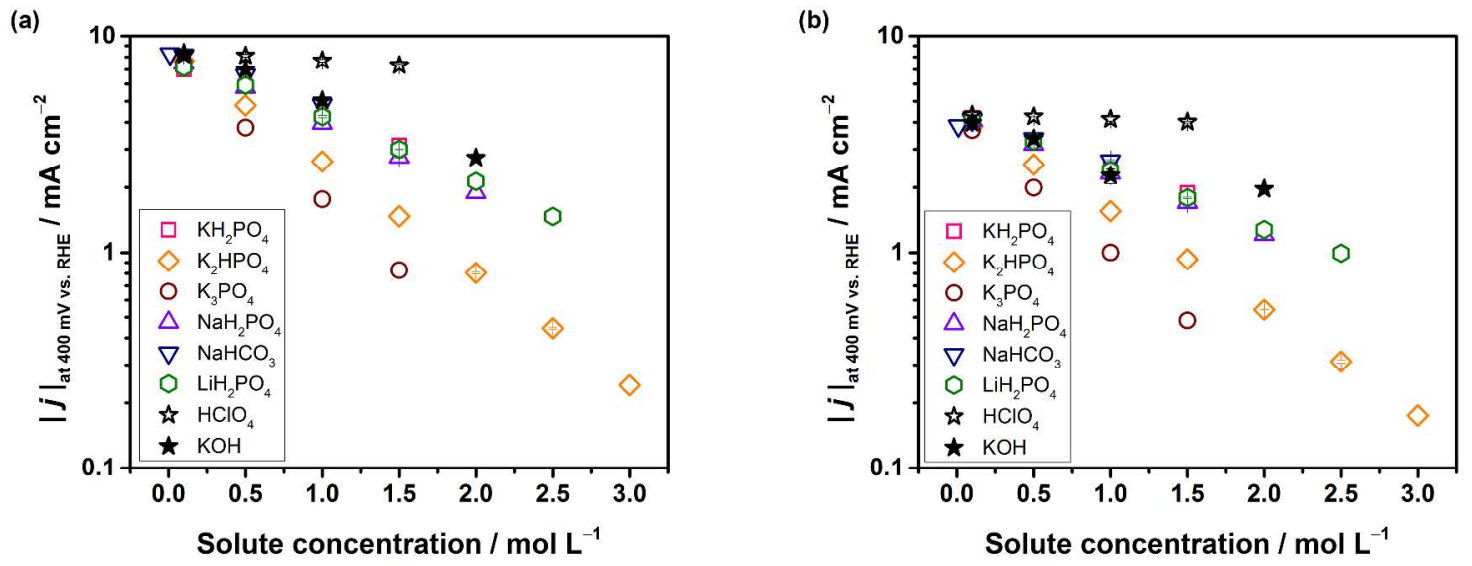
Figure 6. Comparison between current density in oxygen at $-50 \mathrm{mV}$ vs. RHE (y-axis) and summation of current density in oxygen at $400 \mathrm{mV}$ vs. RHE with that in hydrogen at $-50 \mathrm{mV}$ vs. RHE (x-axis), recorded in various electrolyte solutions using a polycrystalline Pt disk electrode (conditions: $-50 \mathrm{mV} \mathrm{s}^{-1}, 3600 \mathrm{rpm}$ and $298 \mathrm{~K}$ ).

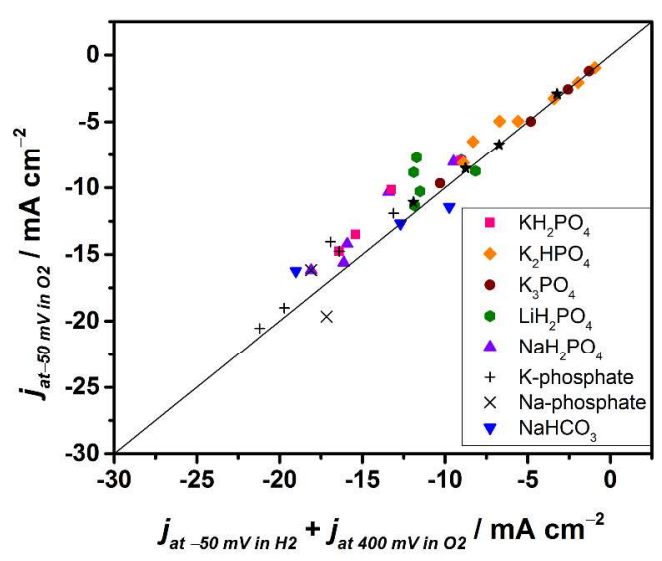


Figure 7. Calculated Faradaic efficiency to the HER in various electrolyte solutions using a polycrystalline Pt disk electrode. a: Various $x$ in $1.5 \mathrm{~mol} \mathrm{~L}^{-1} \mathrm{Na}_{\mathrm{x}} \mathrm{H}_{3-\mathrm{x}} \mathrm{PO}_{4}$ and b: Various $\mathrm{x}$ in 1.5 $\mathrm{mol} \mathrm{L}^{-1} \mathrm{~K}_{\mathrm{x}} \mathrm{H}_{3-\mathrm{x}} \mathrm{PO}_{4}$.

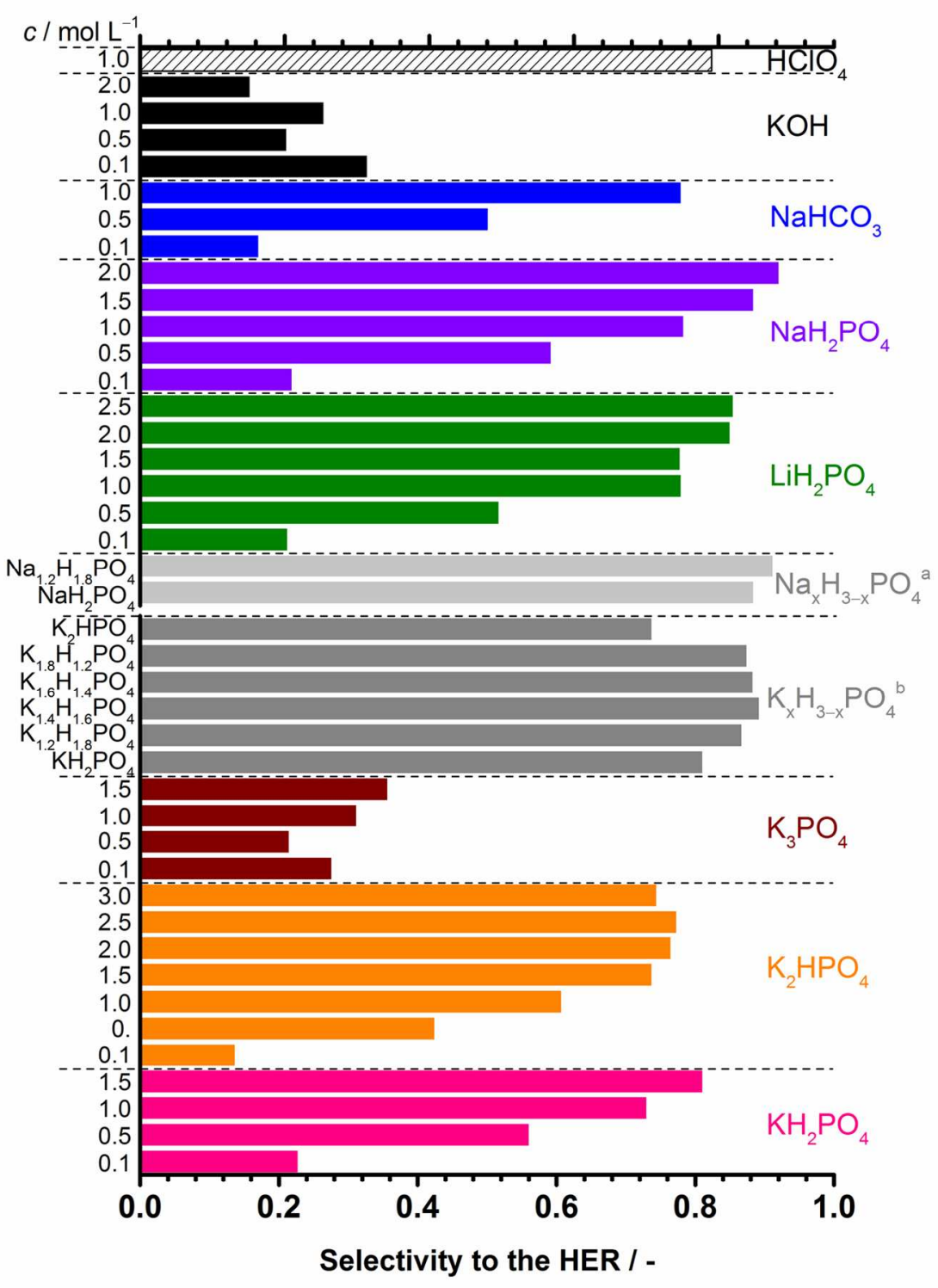


Figure 8. Linear-sweep voltammograms using a polycrystalline Pt disk electrode bubbling with different gases (argon, hydrogen or oxygen) in (a) $2.1 \mathrm{~mol} \mathrm{~L}^{-1} \mathrm{~K}^{+}$and $1.5 \mathrm{~mol} \mathrm{~L}^{-1}$ phosphate, (b) $3.0 \mathrm{~mol} \mathrm{~L}^{-1} \mathrm{~K}_{2} \mathrm{HPO}_{4}$, (c) $1.0 \mathrm{~mol} \mathrm{~L}^{-1} \mathrm{HClO}_{4}$ and (d) $1.0 \mathrm{~mol} \mathrm{~L}{ }^{-1} \mathrm{KOH}$ (conditions: $-50 \mathrm{mV} \mathrm{s}^{-1}$, $3600 \mathrm{rpm}$ and $298 \mathrm{~K})$.
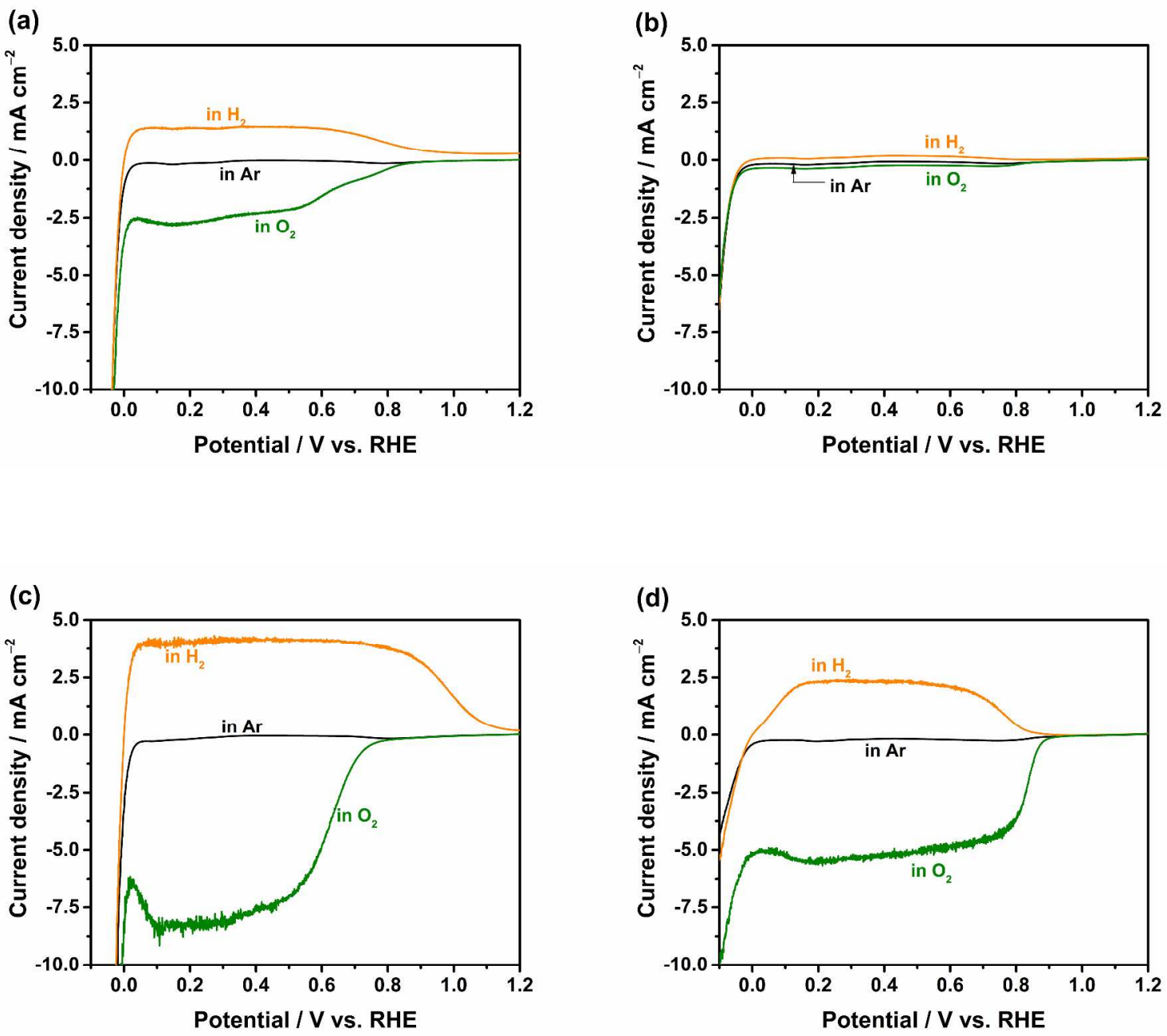
Figure 9. (a) Solution resistivity in various electrolyte solutions measured by impedance (100 $\mathrm{kHz}$, amplitude $10 \mathrm{mV}$ and $298 \mathrm{~K}$ ). Of note, the cell constant in our RDE experimental set up was $1.55 \mathrm{~cm}^{-1}$. 43

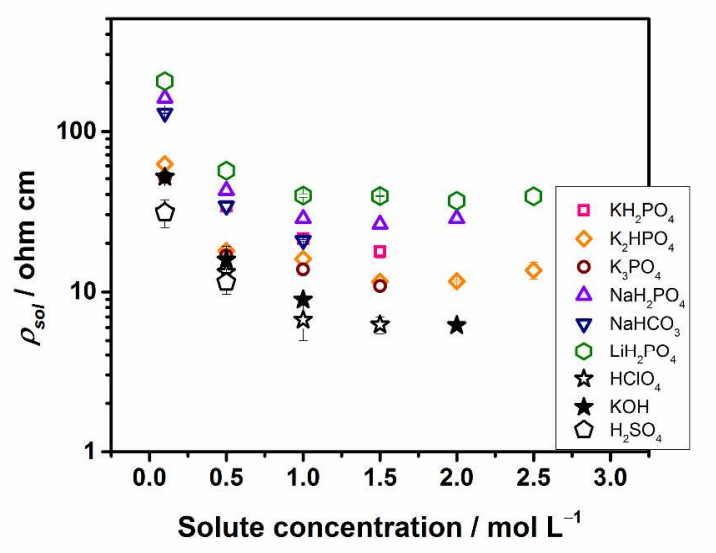


Insert Table of Contents Graphic and Synopsis Here

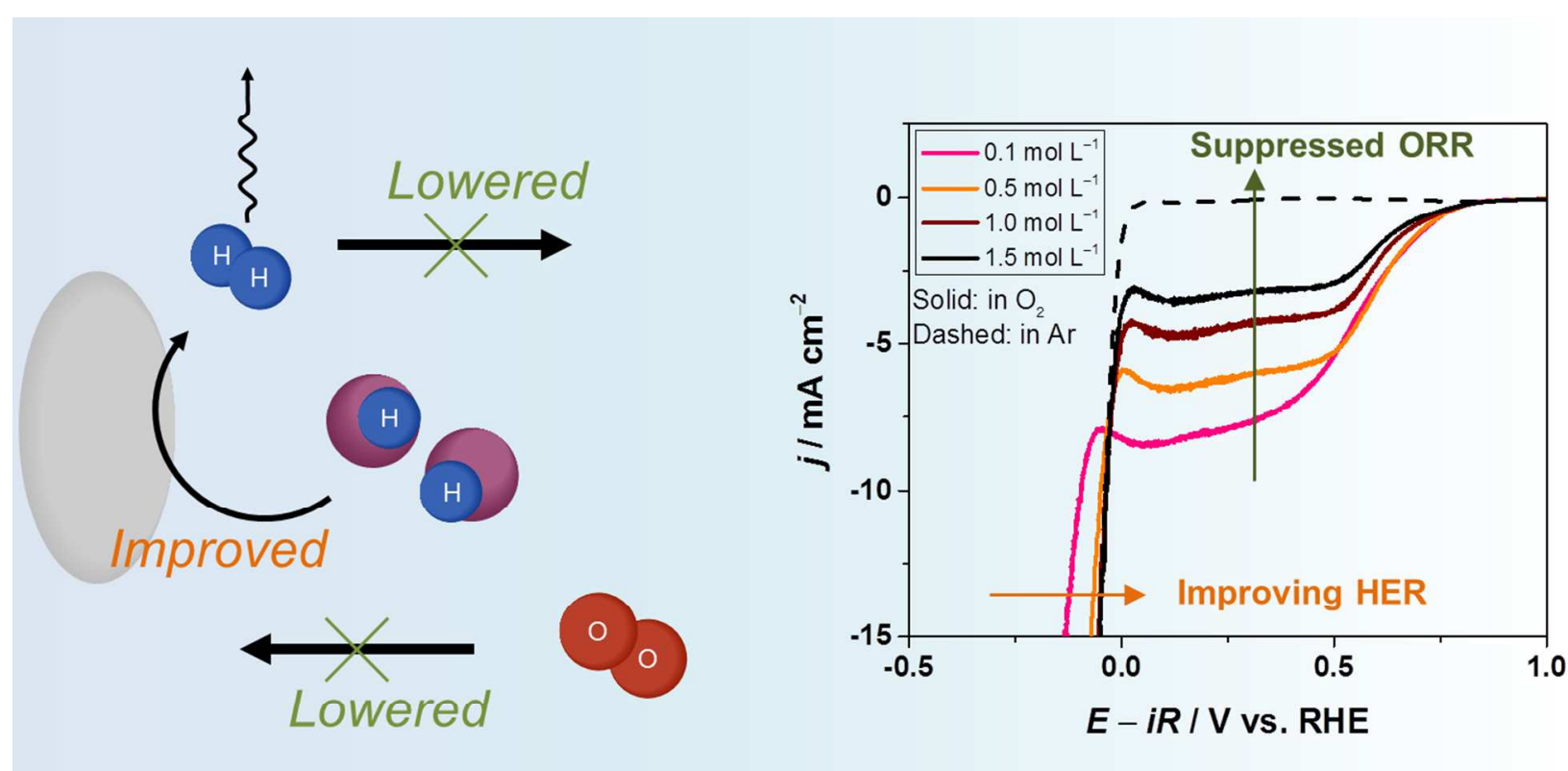

Identity and activity of buffered solution majorly determine gases mass-transport and hydrogen production at near-neutral $\mathrm{pH}$. 